\title{
Pelagic larval growth rate impacts benthic settlement and survival of a temperate reef fish
}

\author{
Jeffrey S. Shima ${ }^{1, *}$, Amy M. Findlay ${ }^{2}$ \\ ${ }^{1}$ Department of Ecology, Evolution, and Marine Biology and the Marine Science Institute, University of California, \\ Santa Barbara, California 93106, USA \\ ${ }^{2}$ Watershed Resource Center Manager, Community Environmental Council, 930 Miramonte Dr., Santa Barbara, \\ California 93109-1348, USA
}

\begin{abstract}
Larvae of marine reef organisms settling into benthic habitats may vary greatly in individual quality. We evaluated potential effects of variation in larval growth rate (1 metric of quality) on larval duration, size-at-settlement, and post-settlement survival of recently settled kelp bass Paralabrax clathratus. We sampled kelp bass daily and weekly from standardized collectors located near the Wrigley Institute for Environmental Studies, Santa Catalina Island, to characterize larval traits of settlers and surviving recruits. Using growth models to fit trajectories of larval otolith growth, we estimated instantaneous larval growth rates and found that these values were good predictors of larval duration and juvenile survival. Kelp bass that grew rapidly as larvae settled $~ 8.5 \mathrm{~d}$ sooner than the slowest growing individuals; both groups had similar sized individuals at settlement, but fast growing larvae experienced enhanced survival during the first $5 \mathrm{~d}$ after settlement relative to slower growing larvae. There is growing evidence suggesting that larval experience continues to exert demographic consequences on subsequent life stages. This helps to explain some of the spatial and temporal variability that characterizes recruitment in marine systems.
\end{abstract}

KEY WORDS: Juvenile performance $\cdot$ Larval quality $\cdot$ Larval traits · Metamorphosis · Physiological condition · Postsettlement survival $\cdot$ Recruitment $\cdot$ Reef fish

Resale or republication not permitted without written consent of the publisher

Understanding the factors that drive population fluctuations is a fundamental goal of ecology. In marine reef systems, attention has focused on processes that drive variability in abundance within pelagic larval stages (Pechenik 1987, Bailey \& Houde 1989, Heath 1992, Morgan 1995, Rissik \& Suthers 2000) or within benthic juvenile stages (Jones 1990, Forrester 1990, Hixon \& Beets 1993, Tupper \& Boutilier 1995, Schmitt

\footnotetext{
*Present address: School of Biological Sciences, Kirk Building, Kelburn Parade, PO Box 600, Victoria University of Wellington, Wellington, New Zealand.

E-mail: jeffrey.shima@vuw.ac.nz
}

\& Holbrook 1996, Shima 2001a,b). Despite inherent connectedness between these life-stages, we lack understanding of the extent to which conditions in one stage influence subsequent stages (reviewed in McCormick 1998, Pechenik et al. 1998).

Body size and physiological condition of adult reef fishes have long been recognized as important determinants of their reproductive capacity (reviewed in Wootton 1990). Evidence from many marine reef organisms suggests that parental condition can also influence egg provisioning and hence the 'quality' of individual progeny. Recent studies demonstrate that variation in larval quality arising from parental effects can impact larval growth (McCormick 1999), development time (Kerrigan 1997, Meidel et al. 1999), and survival (Grønkjær \& Schytte 1999, McCormick 1999, Park et al. 1999, Riveiro et al. 2000). Similarly, the pelagic larval environment (e.g. temperature, food availability, oceanographic features) may also alter rates of larval growth (Hovenkamp \& Witte 1991, Benoît \& Pepin 1999, Otterlei et al. 1999, Keller \& Klein-MacPhee 2000, Rissik \& Suthers 2000), development time (Benoît \& Pepin 1999, Lamare \& Barker 1999, Otterlei et al. 1999, Searcy \& Sponaugle 2000), and survivorship to settlement (Meekan \& Fortier 1996, van der Veer \& Witte 1999, Keller \& Klein-MacPhee 2000) in a variety of marine taxa. However, comparatively few studies have addressed the role of larval quality on the performance (e.g. growth and survivorship) of benthic juvenile stages of marine reef organisms. Several studies of marine invertebrates suggest that a prolonged larval life (i.e. delayed metamorphosis) may reduce post-settlement performance (reviewed in Pechenik 1990, Pechenik et al. 1998), but this observation does not appear to hold true for some reef fish species (Victor 1986a, Cowen 1991). While effects of larval quality on juvenile growth rates have 
been explored in a handful of studies (e.g. Chambers et al. 1988, Bertram et al. 1993, 1997, Jarrett \& Pechenik 1997, Searcy \& Sponaugle 2000, Phillips in press), far fewer studies have attempted to directly address the role of larval quality on post-settlement survival (but see Emlet \& Hoegh-Guldberg 1997, Searcy \& Sponaugle 2001, Phillips in press).

Our primary goal in this study was to explore the consequences of individual variation in larval growth rates on settlement and post-settlement survival of reef fish. We base our analyses on information gained from the otoliths of recently settled kelp bass Paralabrax clathratus. Otoliths of many fishes provide a daily record of previous events, including the length of pelagic larval stages (Brothers et al. 1976, 1983, Victor 1986b, Radtke et al. 1988, Thresher \& Brothers 1989, Wellington \& Victor 1989), timing of settlement (Victor 1982, 1984), identity of parental-source populations (Jones et al. 1999, Swearer et al. 1999), and relative growth rates during different life history stages (Victor 1986a, Thorrold \& Milicich 1990, Jones 1992, Searcy \& Sponaugle 2000). Our study employs correlative approaches to evaluate a range of potential 'larvallegacy' effects that have been hypothesized or documented in other marine organisms.

Materials and methods. Study system and field collection: Our research focused on kelp bass Paralabrax clathratus settlers and juveniles collected from sites near the Wrigley Institute for Environmental Studies, Santa Catalina Island $\left(33^{\circ} 27^{\prime}\right.$ N, $118^{\circ} 29^{\prime}$ W). Kelp bass are common residents of rocky reefs off the coast of California. This species spawns from late spring to early fall, with peak reproduction occurring from July to September (Walker et al. 1987), and routinely settles to our study sites following $\sim 30$ d pelagic larval development period (McClean 1999). Like most reef fish larvae, kelp bass must actively forage through much of their larval period in order to complete development. Competent kelp bass larvae normally settle to the canopies of giant kelp Macrocystis pyrifera, but will readily settle to standardized artificial collectors constructed of plastic mesh (described in Carr 1991, McClean 1999). We used replicate standardized collectors ( $\mathrm{n}=5$ for 1997; $\mathrm{n}=10$ for 1998) deployed $\sim 50 \mathrm{~m}$ apart and $\sim 10 \mathrm{~m}$ off the edge of the reef (e.g. over sand bottom) to sample daily settlement and weekly recruitment of kelp bass at 2 sites ('Rippers Reef' and 'Habitat Reef') separated by $\sim 10 \mathrm{~km}$. Settlement was quantified as the total number of fish removed daily from collectors located on Rippers Reef, and was sampled from 07 August 1997 to 20 August 1997, and from 16 July 1998 to 15 August 1998. Weekly recruitment (the balance of settlement and post-settlement mortality accumulated over a period of up to $7 \mathrm{~d}$ ) was estimated as the total number of fish removed from collectors located on Habitat Reef at weekly intervals between 16 July 1998 and 15 August 1998. For all collected fish, we recorded standard lengths to the nearest $0.01 \mathrm{~mm}$.

Otolith analyses to estimate larval and post-larval attributes: Sagittal otoliths were removed from all collected fish and mounted medial side down on glass slides using cyanoacrylate (Superglue ${ }^{\circledR}$ ) medium. Otoliths that could not be clearly viewed were polished using 3 micron lapping film $\left(3 \mathrm{M}^{\circledR}\right)$ mounted on an 8 inch lapping wheel (Model 920, South Bay Technologies) until increments became clearly visible from the core to the edge of the otolith. Previous studies have validated the presence of daily growth increments (i.e. rings) for this species (Cordes \& Allen 1997), and sub-daily increments were distinguished from daily increments using the criteria of Campana (1984).

Estimates of larval duration and daily growth: All otolith characteristics were quantified using an Olympus ${ }^{\circledR}$ transmitted light microscope at 200 to $400 \times$ with a rotating polarized filter. Images of each otolith were captured using a digital frame-grabber and measurements were made on a 19 inch Trinitron ${ }^{\circledR}$ monitor using a digital image analysis system (ImagePro ${ }^{\circledR}$ v4.0). All measurements were made along the longest radius (from core to outer edge) of each otolith. Positions of daily increments and the settlement check (for weekly recruits only, using criteria of Cordes 1992) along this axis were visually estimated and digitally tagged; the width of each increment (i.e. the distance between successive tags) was calculated and exported to a spreadsheet by the image analysis software. This information allowed us to estimate larval duration, post-settlement age, and daily increment width. Because kelp bass do not appear to produce daily otolith increments until the third day after hatching (Cordes \& Allen 1997), a correction factor of 2 d was added to all estimates of pelagic larval duration. Otoliths were read by only 1 person, and repeated blind estimates of daily increment positions on a random sample $(n=10)$ of these otoliths, made $>30 \mathrm{~d}$ after first reading, produced estimates of (1) larval duration that differed by $<0.4 \mathrm{~d}(1.3 \%$ deviation) on average, and (2) mean daily increment widths that differed by $<0.09 \mu \mathrm{m}$ (1.6\% deviation) on average.

Exponential model to estimate larval growth rates: Daily increment widths during the larval development of kelp bass showed an accelerating relationship with age, and we fitted overall larval growth rates using an exponential growth model:

$$
L_{t}=a \times \exp ^{b t}
$$

where $L_{t}$ is the otolith increment width $(\mu \mathrm{m})$ at time $t(\mathrm{~d})$ in the larval stage, $a$ is the estimated width at $t=0$, and $b$ is the estimated instantaneous larval growth rate. Parameter $b$ measures the 'per $\mu \mathrm{m}$ ' rate of increase over 
a short time interval (units $=\mu \mathrm{m} \mu \mathrm{m}^{-1} \mathrm{~d}^{-1}$ ). Parameters $a$ and $b$ were both initially estimated using a maximum likelihood iterative procedure (NLIN Procedure, SAS v8.2). Although parameter $a$ is potentially useful as an indicator of size at hatch (e.g. arising from parental effects), we found these values to be poorly estimated by the iterative procedure in general, a probable outcome of (1) less precise estimates of increment widths near the otolith core (where increments become very small) and (2) variation in the formation and/or detection of the first daily increment. Because we were primarily concerned with characterizing larval growth rates during the later stages of larval development, we chose to fix parameter $a$ to its mean value (estimated across all samples, $a=10.998 \mu \mathrm{m}$ ) to iteratively obtain estimates of parameter $b$ that were not influenced by uncertainty in parameter $a$.

Effects of larval growth rate on settlement and postsettlement survival: All estimates of growth rates were based on otolith characteristics, and in order to avoid well-documented statistical problems (e.g. Thorrold \& Milicich 1990, Stevenson \& Campana 1992, Secor et al. 1995, Shafer 2000), these estimates were not converted to somatic growth rates. However, the existence of a relationship between otolith growth and somatic growth underlies our interpretations of these data. We therefore used regression to evaluate the relationship between otolith radius and fish standard length for fish collected immediately after settlement (i.e. with no post-settlement growth period); a positive relationship between these metrics is consistent with the widely held notion that otolith growth and somatic growth are often coupled with one another (but see Morales-Nin 2000). These and all subsequent regression and ANOVA analyses were conducted using the GLM procedure of SAS v8.2.

Larval growth rate, larval duration and size-atsettlement: To evaluate the potential influence of larval growth rate on development time, we explored the relationship between pelagic larval duration (number of increments preceding the settlement check) and larval growth rate (parameter $b$ ). Because these attributes could be directly estimated for individuals regardless of their post-settlement age, all collected fish were used for this regression analysis. We evaluated the relationship between size-at-settlement (fish standard length) and larval growth rate using only fish collected at settlement (i.e. without a period of post-settlement growth).

Larval growth rate and post-settlement survival: We explored the potential influence of larval growth rate on post-settlement survival by evaluating shifts in cohort quality (i.e. average larval growth rates for a cohort) as a function of post-settlement cohort age. Such shifts are consistent with selective mortality that may operate differentially on individuals as a function of some attribute of their recent larval histories (e.g. growth rates, size at settlement, lipid stores). Individuals collected from recruitment collectors on Habitat Reef were classified by their post-settlement age (i.e. by the number of otolith increments visible after the settlement check; all samples were determined to be either 3 , 4, or $5 \mathrm{~d}$ old). We then explored variation in larval growth rates among age categories using ANOVA.

Results. Otolith radii measured along their longest axes were a good predictor of the standard lengths of kelp bass measured immediately following settlement $\left(F_{1,96}=243.5, \alpha=0.05, \mathrm{p}<0.0001\right.$; Fig. 1$)$. This result suggests that otolith growth rates averaged over $\sim 30 \mathrm{~d}$ are likely to be a reasonable proxy for somatic growth rates for recently settled kelp bass.

Effects of larval growth rates on larval duration and size-at-settlement: Pelagic development time: Larval duration was negatively correlated with larval growth rate $($ parameter $b)$ for recently settled kelp bass $\left(F_{1,126}=\right.$ 72.93, $\alpha=0.05, p<0.0001$; Fig. 2a). Individuals exhibiting the highest larval growth rates as evidenced by otolith characteristics settled from the pelagic environment $~ 8.5 \mathrm{~d}$ sooner than the slowest growing individuals (based upon best-fit linear regression).

Size-at-settlement: Kelp bass size-at-settlement was poorly related to larval growth rates (Fig. $2 b$ ). The relationship was marginally non-significant $\left(F_{1,96}=3.79\right.$, $\alpha=0.05, p=0.054$ ), and although statistical power was poor $(\beta=0.49)$, the absence of a strong relationship between growth rate and size-at-settlement is likely at-

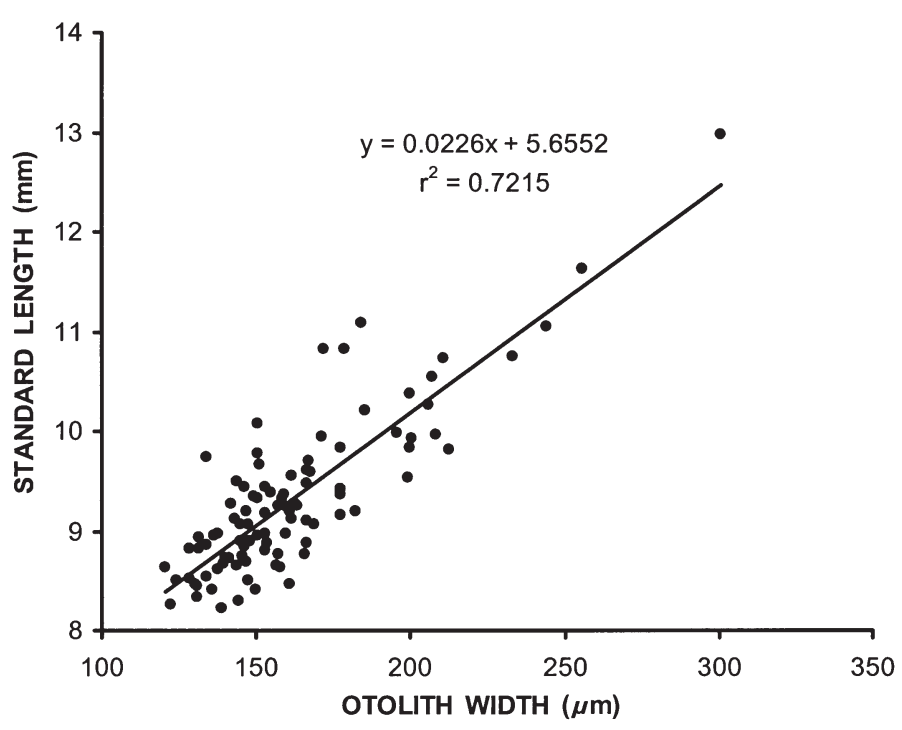

Fig. 1. Relationship between the standard length of kelp bass and maximum radius of their saggital otolith. Linear relationship suggests larval otolith growth is proportional to larval somatic growth for this species 

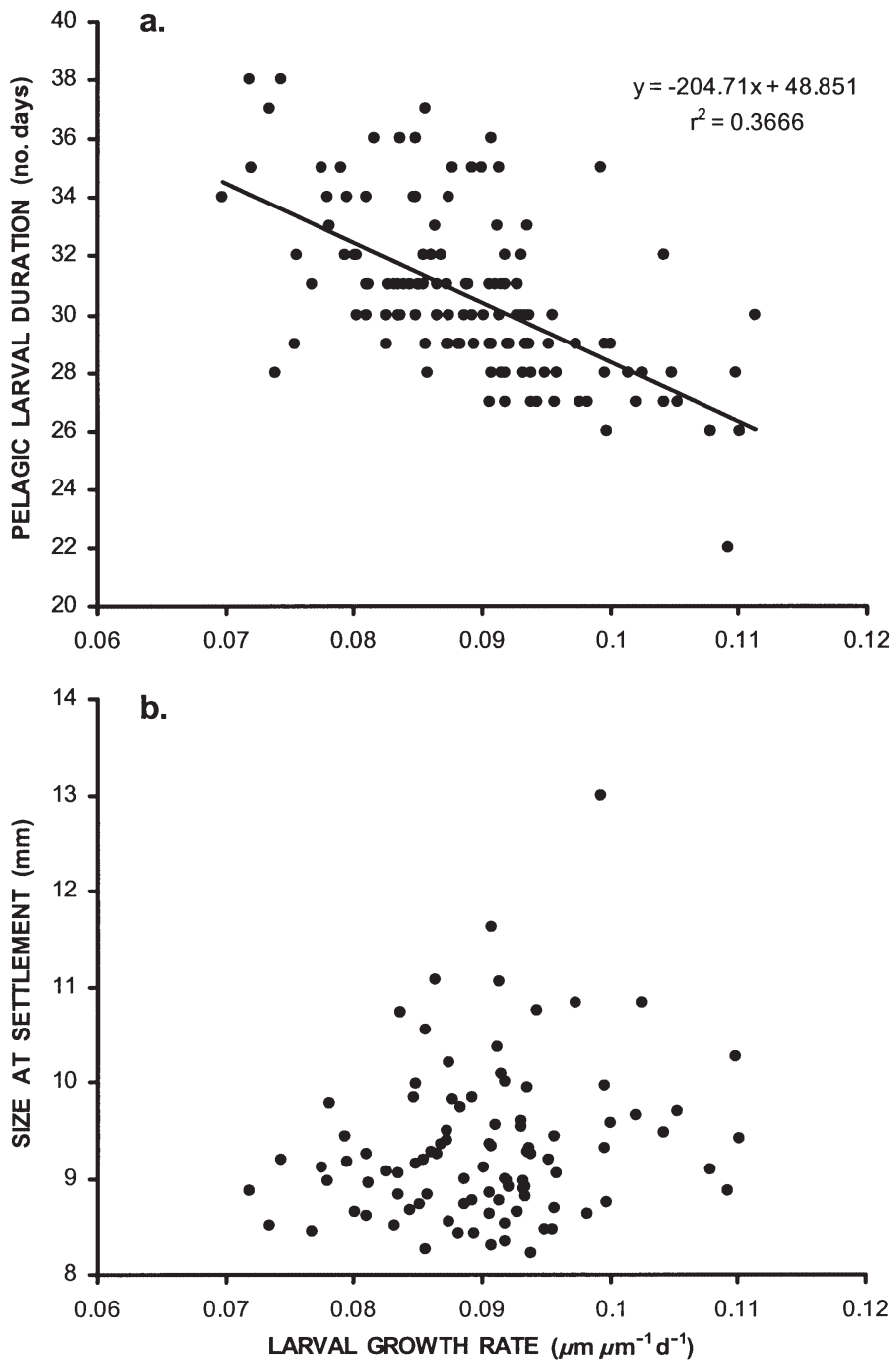

Fig. 2. Effects of individual larval growth rates on (a) larval development time and (b) size-at-settlement. Larval growth rates are the maximum likelihood parameter estimates for otolith growth models (Eq. 1), and represent the 'instantaneous' rate of otolith growth

tributable to the observation that rapidly growing fish appear to settle to benthic habitats sooner (cf. Fig. 2a) rather than delaying settlement to realize a larger size.

Effects of larval growth rates on post-settlement survival: Average larval growth rates varied with postsettlement age of individuals $\left(F_{2,22}=15.78, \alpha=0.05\right.$, $\mathrm{p}<0.0001$; Fig. 3). Recruits collected after $3 \mathrm{~d}$ of life on the reef had instantaneous larval growth rates of

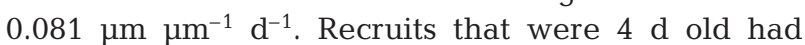
growth rates of $0.087 \mu \mathrm{m} \mu \mathrm{m}^{-1} \mathrm{~d}^{-1}$, while recruits that survived on Habitat Reef for 5 post-settlement d had significantly higher larval growth rates, estimated at $0.102 \mu \mathrm{m} \mu \mathrm{m}^{-1} \mathrm{~d}^{-1}$. Assuming that fish in different age groupings were derived from the same distribution of potential larval growth rates, the significant trend in larval growth rates is consistent with selective mortality that acts with greater frequency upon juveniles that were slow-growing during their larval development.

Discussion. Our results indicate that larval quality impacts settlement and post-settlement survival of a reef fish. Growth rates of larval kelp bass varied substantially over the course of our sampling, and fast larval growth was correlated with reduced larval duration and enhanced survivorship after settlement.

Rapid larval growth rates may be indicative of favorable parental effects (e.g. maternal condition, genetics) and/or pelagic conditions, and may therefore covary with physiological condition at settlement to influence post-settlement survival. Alternatively, protracted larval development (perhaps determined by a larva's encounter rate with suitable habitat) may exact costs that are reflected in survivorship after settlement. Whether larval growth rates determine larval durations, or whether either of these may be implicated as direct causes for variation in post-settlement survival is impossible to ascertain given the correlative nature of our evidence. However, these results contribute to a growing body of evidence (e.g. Emlet \& Hoegh-Guldberg 1997, Pechenik et al. 1998, Searcy \& Sponaugle 2001, Phillips in press) suggesting that larval experience has demographic consequences for subsequent life stages.

Understanding the consequences of variation in larval quality at settlement may help to explain some of the spatial and temporal variation in recruitment that seems to be a hallmark of many marine reef organisms

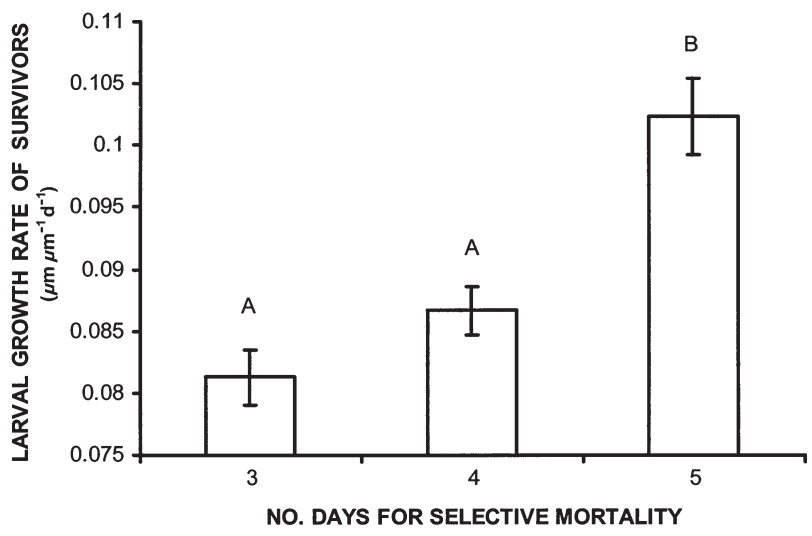

Fig. 3. Paralabrax cathratus. Instantaneous larval growth rates by post-settlement age of cohorts; mean $( \pm 1 \mathrm{SE})$ larval growth rates for fish collected weekly from Habitat Reef. Collected fish were determined to be $3(n=8), 4(n=12)$, or $5(\mathrm{n}=5)$ post-settlement days old (based upon positions of otolith settlement check). Results of post hoc Tukey tests are given above each bar, and different letters indicate significant shifts in larval growth rate distributions consistent with condition-selective mortality 
(Loosanoff 1964, Caffey 1985, Cowen 1985, Doherty 1991, Caley et al. 1996). Variation in larval quality at settlement may influence post-settlement densitydependent interactions that regulate local populations (e.g. Shima \& Osenberg unpubl.), and recent work on marine invertebrates suggests that consequences of variability in larval quality at settlement may be contingent upon post-settlement habitat quality (Moran \& Emlet 2001).

Furthermore, larval quality may play an important role in marine metapopulations. Local populations that produce larvae of higher quality, or populations that export larvae into pelagic conditions that result in higher larval quality may contribute proportionally more offspring to subsequent generations than local populations producing larvae of relatively poor quality. Similarly, coupling between local larval production and recruitment (i.e. self-recruitment) may be enhanced if hydrographic features aggregate and retain larvae in high food environments, resulting in retained larvae that are of higher fitness relative to larvae that have dispersed over greater distances (e.g. Swearer et al. 1999). Understanding the patterns and consequences of variations in larval quality may be critical to the design and positioning of effective marine reserves.

Our results characterize individual variation in lifehistory traits to estimate growth rate curves. Pooling of data can mask evidence of selective mortality (Crowder et al. 1992, Litvak \& Legget 1992, Pepin et al. 1992, Chambers \& Miller 1995). Overall, this work suggests a greater need to incorporate individual-based metrics, ideally, coupled with manipulative experiments to determine the role of larval legacies on the recruitment success of marine reef organisms.

Acknowledgements. Field work for this project was supported by a graduate internship to A. Findlay (formerly McClean) from USC Wrigley Institute for Environmental Studies on Santa Catalina Island, funding from the Nearshore Marine Fish Research Program at CSU Northridge, and a grant from the Student Projects Committee at CSU Northridge. Field work would not have been possible without the kind support and advice of L. Allen, and generous assistance of S. Anderson, D. Conlin, P. Dixon, K. Flanagan, S. Grunwald, J Hooykaas, M. Hughes, J. Malone, H. Stewart, K. Wisenbaker, and C. Yonker. Logistical support was kindly provided by the staff at Wrigley Institute. Support and facilities for otolith analyses were provided by PISCO (Partnership for the Interdisciplinary Study of Coastal Oceans - a grant from the David and Lucile Packard Foundation), and the Santa Barbara Coastal LTER Program (OCE 9982105 to D. Reed). M. Sheehy and S. Swearer generously provided advice on otolith preparation and analysis, and versions of this manuscript greatly benefited from discussions with N. Phillips, S. Gaines, S. Swearer, and the comments of A. Brooks, J. Byers, N. Phillips, C. Peterson, and 2 anonymous reviewers. This paper is contribution number 80 from PISCO, 221 of the Wrigley Institute of Environmental Studies.

\section{LITERATURE CITED}

Baily KM, Houde ED (1989) Predation on eggs and larvae of marine fishes and the recruitment problem. Adv Mar Biol 25:1-83

Benoît HP, Pepin P (1999) Individual variability in growth rate and the timing of metamorphosis in yellowtail flounder Pleuronectes ferrugineus. Mar Ecol Prog Ser 184:231-244

Bertram DF, Chambers RC, Leggett WC (1993) Negative correlations between larval and juvenile growth rates in winter flounder: implications of compensatory growth for variation in size-at-age. Mar Ecol Prog Ser 96:209-215

Bertram D, Miller T, Leggett W (1997) Individual variation in growth and development during the early life stages of winter flounder, Pleuronectus americanus. Fish Bull 95:1-10

Brothers EB, Mathews CP, Lasker R (1976) Daily growth increments in otoliths from larval and adult fish. Fish Bull 74:1-8

Brothers EB, Williams DM, Sale PF (1983) Length of larval life in twelve families of fishes at 'One Tree Lagoon', Great Barrier Reef, Australia. Mar Biol 6:319-324

Caffey H (1985) Spatial and temporal variation in settlement and recruitment of intertidal barnacles. Ecol Monogr 55: 313-332

Caley MJ, Carr MH, Hixon MA, Hughes TP, Jones GP, Menge BA (1996) Recruitment and the local dynamics of open marine populations. Annu Rev Ecol Syst 27:477-500

Campana SE (1984) Interactive effects of age and environmental modifiers on the production of daily growth increments in otoliths of plainfin midshipman, Porichthys notatus. Fish Bull 82:165-177

Carr MH (1991) Patterns, mechanisms and consequences of recruitment of a temperate marine fish. $\mathrm{PhD}$ thesis, University of California, Santa Barbara, CA

Chambers RC, Miller TJ (1995) Evaluating fish growth by means of otolith increment analysis: special properties of individual level longitudinal data. In: Secor DH, Dean JM, Campana SE, Miller AB (eds) Recent developments in otolith research. University of South Carolina Press, SC, p 155-175

Chambers RC, Leggett WC, Brown JA (1988) Variation in and among early life history traits of laboratory-reared winter flounder Pseudopleuronectes americanus. Mar Ecol Prog Ser 47:1-15

Cordes JF (1992) Age, growth, spawning periodicity, settlement and distribution of the young-of-the-year and older juvenile kelp bass (Paralabrax clathratus) in the Southern California Bight during 1988-1990. MS thesis, California State University, Northridge

Cordes JF, Allen LG (1997) Estimates of age, growth, and settlement from otoliths of young-of-year kelp bass (Paralabrax clathratus). Bull South Calif Acad Sci 96:43-60

Cowen RK (1985) Large scale pattern of recruitment by the labrid Semicossyphus pulcher: causes and implications. J Mar Res 43:719-742

Cowen RK (1991) Variation in the planktonic larval duration of the temperate wrasse Semicossyphus pulcher. Mar Ecol Prog Ser 69:9-15

Crowder LB, Rice JA, Miller TJ, Marschall EA (1992) Empirical and theoretical approaches to size-based interactions and recruitment variability in fishes. In: DeAngeles DL, Gross LJ (eds) Individual-based models and approaches in ecology: populations, communities, and ecosystems. Chapman \& Hall, New York, p 237-255

Doherty PJ (1991) Spatial and temporal patterns in recruitment. In: Sale PF (ed) The ecology of fishes on coral reefs. Academic Press, San Diego, CA, p 261-293 
Emlet, RB, Hoegh-Guldberg, O (1997) Effects of egg size on postlarval performance: Experimental evidence from a sea urchin. Evolution 51:141-152

Forrester GE (1990) Factors influencing the juvenile demography of a coral reef fish. Ecology 71:1666-1681

Grønkjæer P, Schytte M (1999) Non-random mortality of Baltic cod larvae inferred from otolith hatch-check sizes. Mar Ecol Prog Ser 181:53-59

Heath MR (1992) Field investigrations of the early life stages of marine fish. Adv Mar Biol 28:1-174

Hixon MA, Beets JP (1993) Predation, prey refuges, and the structure of coral reef fish assemblages. Ecol Monogr 63: $77-101$

Hovenkamp F, Witte JIJ (1991) Growth, otolith growth and RNA/DNA rations of larval plaice Pleuronectes platessa in the Southern Bight of the North Sea 1987-1989. Mar Ecol Prog Ser 70:105-116

Jarrett JN, Pechenik J (1997) Temporal variation in cyprid quality and juvenile growth capacity for an intertidal barnacle. Ecology 78(4):1262-1265

Jones CM (1992) Development and application of the otolith increment technique. In: Stevenson DK, Campana SE (eds) Otolith microstructure: examination and analysis. Special publ. Can Fish Aquat Sci 117:1-11

Jones GP (1990) The importance of recruitment to the dynamics of a coral reef fish population. Ecology 71:1601-1698

Jones GP, Milicich MJ, Emslie MJ, Lunow C (1999) Selfrecruitment in a coral reef fish population. Nature 402: 802-804

Keller AA, Klein-MacPhee GK (2000) Impact of elevated temperature on growth, survival, and trophic dynamics of winter flounder larvae: a mesocosm study. Can J Fish Aquat Sci 57:2382-2392

Kerrigan BA (1997) Variability in larval development of the tropical reef fish Pomacentrus amboinensis (Pomacentridae): the parental legacy. Mar Biol 127:395-402

Lamare M, Barker M (1999) In situ estimates of larval development and mortality in the New Zealand sea urchin Evechinus choroticus (Echinodermata: Echinoidea). Mar Ecol Prog Ser 180:197-211

Litvak MK, Leggett WC (1992) Age and size-selective predation on larval fishes: the bigger-is-better hypothesis revisited. Mar Ecol Prog Ser 81:13-24

Loosanoff VL (1964) Variations in time and intensity of the settling starfish, Asterias forbesi, in Long Island Sound during a twenty-five year period. Biol Bull 126:423-439

McClean AM (1999) Settlement patterns of a temperate reef fish, Paralabrax clathratus, at Santa Catalina Island, CA. MS thesis, California State University, Northridge, CA

McCormick MI (1998) Condition and growth of reef fish at settlement: Is it important? Aust J Ecol 23:258-264

McCormick M (1999) Experimental test of the effect of maternal hormones on larval quality of a coral reef fish. Oecologia 118:412-422

Meekan MG, Fortier L (1996) Selection for fast growth during the larval life of Atlantic cod Gadus morhua on the Scotian Shelf. Mar Ecol Prog Ser 137:25-37

Meidel SK, Scheibling RE, Metaxas A (1999) Relative importance of parental and larval nutrition on larval development and metamorphosis of the sea urchin Strongylocentrotus droebachiensis. J Exp Mar Biol Ecol 240:161-178

Morales-Nin B (2000) Review of the growth regulation processes of otolith daily increment formation. Fish Res 46: $53-63$

Moran AL, Emlet RB (2001) Offspring size and performance in variable environments: field studies on a marine snail. Ecology 82:1597-1612
Morgan SG (1995) Life and death in the plankton: Larval mortality and adaptation. In: McEdward L (ed) Ecology of marine invertebrate larvae. CRC Press, Boca Raton, FL, p 13-24

Otterlei E, Nyhammer G, Folkvord A, Stefansson S (1999) Temperature- and size-dependent growth of larval and early juvenile Atlantic cod (Gadus morhua): a comparative study of Norwegian coastal cod and northeast Arctic cod. Can J Fish Aquat Res 56:2099-2111

Park M, Lim H, Jo Q, Yoo J, Jeon M (1999) Assessment of reproductive health in the wild seed oysters, Crassostrea gigas, from two locations in Korea. J Shelf Res 18: $445-450$

Pechenik J (1987) Environmental influences on larval survival and development. In: Giese AC, Pearse JS, Pearse VB (eds) Reproduction of Marine Invertebrates, Vol 9. Blackwell Scientific Publications, Palo Alto, CA, p 551-608

Pechenik J (1990) Delayed metamorphosis by larvae of benthic marine invertebrates: Does it occur? Is there a price to pay? Ophelia 32:63-94

Pechenik J, Wendt D, Jarrett J (1998) Metamorphosis is not a new beginning. BioScience 48:901-910

Pepin P, Shears TH, Lafontaine Y de (1992) Significance of body size to the interaction between a larval fish (Mallotus villosus) and a vertebrate predator (Gasterosteus aculeatus). Mar Ecol Prog Ser 81:1-12

Phillips $\mathrm{N}$ (in press) Effects of nutrition-mediated larval condition on juvenile performance in a marine mussel. Ecology

Radtke RL, Kinzie RA, Folsom SD (1988) Age at recruitment of Hawaiian freshwater gobies. Environ Biol Fish 23: 205-214

Rissik D, Suthers I (2000) Enhanced feeding by pelagic juvenile myctophid fishes within a region of island-induced flow disturbance in the Coral Sea. Mar Ecol Prog Ser 203: $263-273$

Riveiro I, Guisande C, Lloves M, Maneiro I, Cabanas J (2000) Importance of parental effects on larval survival in Sardina pilchardus. Mar Ecol Prog Ser 205:249-258

Schmitt RJ, Holbrook SJ (1996) Local-scale patterns of larval settlement in a planktivorous damselfish - do they predict recruitment? Aust J Mar Freshw Res 47:449-463

Searcy SP, Sponaugle S (2000) Variable larval growth in a coral reef fish. Mar Ecol Prog Ser 206:213-226

Searcy SP, Sponaugle S (2001) Selective mortality during the larval-juvenile transition in two coral reef fishes. Ecology 82:2452-2470

Secor DH, Dean JM, Campana SE, Miller AB (1995) Recent developments in otolith research. University of South Carolina Press, Columbia, SC

Shafer DJ (2000) Evaluation of periodic and aperiodic otolith structure and somatic-otolith scaling for use in retrospective life-history analysis of a tropical marine goby, Bathygobius coalitus. Mar Ecol Prog Ser 199:217-229

Shima JS (2001a) Recruitment of a coral reef fish: roles of settlement, habitat, and postsettlement losses. Ecology 82: 2190-2199

Shima JS (2001b) Regulation of local populations of a coral reef fish via joint effects of density- and number-dependent mortality. Oecologia 126:58-65

Stevenson DK, Campana SE (1992) Otolith microstructure examination and analysis. Spec Publ Can J Fish Aquat Sci 117

Swearer SE, Caselle J, Lea D, Warner R (1999) Larval retention and recruitment in an island population of a coral reef fish. Nature 402:799-802

Thorrold SR, Milicich MJ (1990) Comparison of larval dura- 
tion and pre- and post-settlement growth in two species of damselfish, Chromis atripectoralis and C. Pomacentrus coelestis (Pisces: Pomacentridae), from the Great Barrier Reef. Mar Biol 105:375-384

Thresher RE, Brothers EB (1989) Evidence of intra- and interoceanic regional differences in the early life history of reef-associated fishes. Mar Ecol Prog Ser 57:187-205

Tupper M, Boutilier R (1995) Effects of habitat on settlement, growth, and post-settlement survival of Atlantic cod (Gadus morhua). Can J Fish Aquat Sci 52:1834-1841

van der Veer HW, Witte JIJ (1999) Year-class strength of plaice Pleuronectes platessa in the Southern Bight of the North Sea: a validation and analysis of the inverse relationship with winter seawater temperature. Mar Ecol Prog Ser 184:245-257

Victor BC (1982) Daily otolith increments and recruitment in two coral-reef wrasses, Thalassoma bifasciatum and Halichoeres bivittatus. Mar Biol 71:203-208

Editorial responsibility: Charles Petersen (Contributing Editor), Morehead City, North Carolina, USA
Victor BC (1984) Coral reef fish larvae: patch size estimation and mixing in the plankton. Limnol Oceanogr 29: 1116-1119

Victor BC (1986a) Larval settlement and juvenile mortality in a recruitment-limited coral reef fish population. Ecol Monogr 56:1435-1460

Victor BC (1986b) Duration of the planktonic larval stage of one hundred species of Pacific and Atlantic wrasses (family Labridae). Mar Biol 90:317-326

Walker HJ, Watson W, Barnett AM (1987) Seasonal occurrence of larval fishes in the nearshore southern California Bight off San Onofre, California. Estuar Coast Shelf Sci 25:91-109

Wellington GM, Victor BC (1989) Planktonic larval duration of one hundred species of Pacific and Atlantic damselfishes (Pomacentridae). Mar Biol 101:557-567

Wootton RJ (1990) Ecology of teleost fishes. Chapman \& Hall, London

Submitted: July 25, 2001; Accepted: February 21, 2002

Proofs received from author(s): May 10, 2002 